\title{
Comparative study between the effect of Momordica charantia (wild and hybrid variety) on hypoglycemic and hypolipidemic activity of alloxan induced type 2 diabetic long-evans rats
}

\author{
Subbroto Kumar Saha ${ }^{1 *}$, Md. Ezazul Haque ${ }^{1}$, Dipa Islam², Md. Matiar Rahman³, \\ Md. Rezuanul Islam ${ }^{1}$, Anzana Parvin ${ }^{1}$, Shahedur Rahman ${ }^{4}$ \\ ${ }^{1}$ Department of Biotechnology \& Genetic Engineering, Islamic University, Kushtia, Bangladesh; \\ *Corresponding Author: subbroto1986@yahoo.com, \\ ezazulbge@gmail.com, rezwangbt@yahoo.com, labonno16@yahoo.com \\ ${ }^{2}$ Institute of Food Science \& Technology (IFST), BCSIR, Dhaka, Bangladesh; dipa_ifst@yahoo.com \\ ${ }^{3}$ Department of Statistic, Islamic University, Kushtia, Bangladesh; moti du@yahoo.com \\ ${ }^{4}$ Department of Genetic Engineering and Biotechnology, Jessore Science \& Technology University, Jessore, Bangladesh; \\ shahed.rajib@gmail.com
}

Received 6 November 2011; revised 10 December 2011; accepted 23 December 2011

\begin{abstract}
This study was undertaken to evaluate the hypoglycemic and hypolipidemic effect of Momordica charantia (wild and hybrid variety) powder on alloxan induced type 2 diabetic male LongEvans rats. Oral feeding of the $M$. charantia powder slightly decreased serum total cholesterol, triglyceride levels and LDL-cholesterol compared with wild, hybrid and standard drug. M. charantia wild variety showed more significant $(p<0.05$, $0.01,0.001$ ) effect on blood glucose level when compared with hybrid variety and standard drug (glibenclamide, $5 \mathrm{mg} / \mathrm{kg}$ ). At the same time rats' serum insulin level markedly increased, wild variety showed more significant $(p<0.05,0.01$, 0.001) than glibenclamide control group and hybrid group. But $M$. charantia did not show any significant effect on HDL-cholesterol and liver glycogen. Thus, results of the study prove that the wild variety of $M$. charantia fruit have potent antidiabetic and antilipidemic property.
\end{abstract}

Keywords: Type 2 Diabetes Mellitus; Momordica charantia; Alloxan, Hypoglycemic Effect;

Hypolipidemic Effect; Glibenclamide

\section{INTRODUCTION}

Diabetes mellitus (DM) is a major degenerative disease in the world today [1], affecting at least 15 million people and having complications which include hyper- tension, atherosclerosis and microcirculatory disorders [2]. Diabetes mellitus is also associated with long-term complications, including retinopathy, nephropathy, neuropathy and angiopathy and several others [3]. Diabetes mellitus a heterogeneous group of disorders characterized by hyperglycemia, is one of the commonest endocrine and metabolic disorders affecting mankind all over the world. It is defined as a group of metabolic diseases characterized by hyperglycemia resulting from defects in insulin secretion, insulin action, or both [4,5]. It is the most common endocrine disorder and by the year 2010 it is estimated that more than 200 million people worldwide will have DM and 300 million will subsequently have the disease by 2025 [6]. Diabetes mellitus is ranked seventh among the leading causes of death and is considered third when its fatal complications are taken into account [7]. Hyperlipidemia characterized elevated serum total cholesterol and low density and very low density lipoprotein cholesterol and decrease high density lipoprotein are the risk factor for coronary heart diseases. Hyperlipidemia associated lipid disorders are considered to cause the atherosclerotic cardiovascular disease $[8,9]$. Hyperglycemia and Hyperlipidemia is implicated as the cause for coronary heart diseases. For treating Type 2 diabetic subjects, when patients fail to maintain normoglycemia by maintaining diet and exercise alone, the first line drugs are the Oral Hypoglycemic agents (OHAs), Sulphonylurea, Biguanides, thiozolidinedions [10], Meglitinides [11], metformin, glibenclamide, Glipizides and Glimipirides are the drug of choice. Though varieties of synthetic drugs are used in the treatment, still the searches are on for better medicaments especially from 
the plant kingdom. Many medicinal plants have been studied in this context [12]. Several plant species have been described as hypoglycemic and hypolipidemic effect, More than 400 species have been reported to display hypoglycemic effects, but only a few of them have been investigated [13-16]. Momordica charantia is one of them. Bitter melon has been used in various Asian and African traditional medicine systems for a long time [17]. The anti-diabetic components in bitter melon include charantin, vicine, polypeptide-p, alkaloids and other nonspecific bioactive components such as anti-oxidants. The present research program was under taken to investigate hypoglycemic and hypolipidemic comparative activities of fruits powder of wild and hybrid Momordica charantia on alloxan induced diabetic model rats.

\section{MATERIALS AND METHODS}

\subsection{Place of the Study}

The study was conducted in the Animal Research Section, Institute of Food Science \& Technology (IFST), Bangladesh Council of Scientific and Industrial Research (BCSIR), Dhaka, Bangladesh. The study was done during the period of February 2010 to July 2010.

\subsection{Plant Material}

The fruit of Momordica charantia were collected from Mongolbaria bazzar, kushtia and Raer bazzar, Dhaka, Bangladesh and was identified by the Bangladesh National Herbarium, Dhaka.

\subsection{Preparation of $M$. charantia Fruits Powder}

The fruits were sliced into small pieces, before the fruits washed carefully with rinsed water. The fresh sliced fruits were air dried and then oven dried at $37^{\circ} \mathrm{C}$ temperature. The dried fruits were then grinded to make powder, which were then screened to get fine powder. 10 $\mathrm{kg}$ of wild fruits dried in oven yielded $1000 \mathrm{gm} \& 10 \mathrm{~kg}$ of hybrid fruits dried in oven yielded 1000 gm of $M$. charantia fruits powder.

\subsection{Animals Used}

Healthy male rats (Long-Evans) of local strain, weighting 142 - 170 gm were used in these experiments. Before using the rat for experiment, rats were kept under observation for a week and maintained at a constant room temperature of $22^{\circ} \mathrm{C} \pm 5^{\circ} \mathrm{C}$ with humidity of $40 \%-70 \%$ and the natural 12 hours day-night cycle, in animal house of Animal Research Section, Institute of Food Science \& Technology (IFST), Bangladesh Council for Scientific and Industrial Research (BCSIR), Dhaka, Bangladesh.
The animals were offered a balanced rat's diet fed on a standard laboratory pellet diet and water supplied ad $l i$ bitum, access to food except during the day of experimental procedure.

A total number of 30 rats were used to carry out the experiments, which include only type, 2 diabetic model rats. Each type of experimental models was divided into five groups. Each individual group contained 5 rats, matched with body weight. These include:

1) Group-A: fed powder of $M$. charantia wild $50 \%+$ $50 \%$ normal rat diet (wild 50\%);

2) Group-B: fed powder of M. charantia wild 30\% + $70 \%$ normal rat diet (wild 30\%);

3) Group-C: fed powder of M. charantia hybrid 50\% + $50 \%$ normal rat diet (hybrid 50\%);

4) Group-D: fed powder of M. charantia hybrid 30\% + 70\% normal rat diet (hybrid 30\%);

5) Group-E (fed with glibenclamide);

6) Group-F (fed normal rat diet).

\subsection{Preparation of Diabetic Rats}

The rats were made diabetic by injecting alloxan monohydrate 150-mg/Kg-body weight intravenously [18]. Alloxan is a toxic glucose analogue, which selectively destroys insulin-producing cells in the pancreas when administered to rodents and many other animal species. This causes an insulin-dependent diabetes mellitus (called "Alloxan Diabetes") in these animals, with characteristics similar to type 1 diabetic in humans [19]. But I injected $125-\mathrm{mg} / \mathrm{Kg}$-body alloxan into inter peritoneum (I.P). This dose permanently destroys the $\beta$ cells of pancreas and produces diabetes mellitus. After three days, blood glucose of all the surviving rats was determined by the Diagnostics Elitech method. Rats with blood glucose levels above $6 \mathrm{mmol} / \mathrm{l}$ are considered as diabetic and employed for further study. For the evaluation of the hypoglycemic activity, the powder of the $M$. charantia fruits were administered orally at a dose of daily 36 g/kg-rat body weight (50\%) and 21 gm/kg-rat body weight (30\%) for 21 days. For all the pharmacological studies, the drug glibenclamide administrated as a drug control, at a dose of $5 \mathrm{mg} / 10 \mathrm{ml}\left(9.9 \mathrm{ml} \mathrm{H}_{2} \mathrm{O}+0.1 \mathrm{ml}\right.$ Twin 20)/kg body weight for Type 2 model rats. Fasting blood samples were collected on day $3^{\text {rd }}$ (initial), $8^{\text {th }}, 15^{\text {th }}$ and $22^{\text {nd }}$ by amputation of the tail tip under diethyl ether anesthesia. Just before cutting the tail was immersed into warm water $\left(40^{\circ} \mathrm{C}\right)$ for approximately 22 seconds for vasodilatation. The level of blood glucose was determined $3^{\text {rd }}$ (initial), $8^{\text {th }}, 15^{\text {th }}$ and $22^{\text {nd }}$ day sample. After cutting the tail tip about $0.2 \mathrm{ml}$ blood was taken cautiously. And the blood glucose level was measured by glucometar (Aqua check). The $22^{\text {nd }}$ day's collected blood were centrifuged after $20 \mathrm{~min}$ at $4000 \mathrm{rpm}$ for $10 \mathrm{~min}$ 
and re-centrifuged at $2000 \mathrm{rpm}$ for $5 \mathrm{~min}$. the serums were separated and taken into eppendorfs. Fasting and $21^{\text {st }}$ day glucose, serum triglyceride, total cholesterol, High-Density Lipoprotein Cholesterol (HDL-C) and LowDensity Lipoprotein Cholesterol (LDL-C) serum insulin were measured.

\subsection{Statistical Analysis}

Data from the experiments were analyzed using the Statistical Package for Social Science(SPSS) software for windows version 14.0 (SPSS Inc., Chicago, Illinois, USA). All the data were expressed as mean \pm SD. Statistical analysis of the results was performed by using the student's t-test (paired and unpaired) or ANOVA (analysis of variance) followed by Bonferroni post hoc test. The limit of significance was set at $\mathrm{p}<0.05, \mathrm{p}<0.01$ and $\mathrm{p}<0.001$.

\section{RESULTS}

\subsection{Chronic Effect of M. charantia (Wild \& Hybrid) Powder on Fasting Blood Glucose Concentration of Alloxan Induced Type 2 Diabetic Model Rats}

The results of effect of powder of $M$. charantia (wild and hybrid) $50 \%$ and 30\% which are expressed as change in blood glucose level are shown in Table 1 \& Figure 1 respectively. More significant ( $p<0.05,0.01,0.001$ ) anti-diabetic activity was observed in wild 50\% \& 30\% and hybrid $50 \% \& 30 \%$ in initial, $8^{\text {th }}, 15^{\text {th }}$ and $22^{\text {nd }}$ chronic alloxan induced type two model compared with standard glibenclamide (drug control) and normal control In vivo efficiency was performed in healthy normal Long Evans rats by measuring the hypoglycemic effect produced after oral administration. Khan and Shechter have suggested that a $25 \%$ reduction in blood glucose levels is considered a significant hypoglycemic effect [20]. The results of the study were satisfactory and revealed that the wild 50\% \& 30\% and hybrid 50\% \& 30\% has exhib- ited significant $(\mathrm{p}<0.05)$ hypoglycemic activity. The reduction of blood glucose level in alloxan induced rat was found highest $65 \%$ in M. charentia (wild 50\%) as the standard drug (glibenclamide).

\subsection{Chronic Effect of M. charantia (Wild \& Hybrid) Powder on Fasting Serum Lipidemic Status (Total Cholesterol and Triglyceride) of Alloxan Induced Type 2 Diabetic Rats}

The mean serum total cholesterol and triglyceride levels of normal control, drug control and powder of $M$. charantia (wild and hybrid) treated animals (after intravaineal administration of a single dose) on the 21 day are shown in Table 2 \& Figures 2, 3 respectively. The hypolipidemia was observed in animals treated with powder of $M$. charantia (wild and hybrid). To determine whether there was a statistically significant difference in hypolipidemia achieved by the powder on the $22^{\text {nd }}$ day, the oneway ANOVA (Bonferroni p test) was applied and compared with the control group. A very rare significant reduction $(\mathrm{P}<0.05)$ in fasting serum total cholesterol of $13 \%$, 5.3\%, 9.48\%, 2.4\% and $15.08 \%$ was observed on the $22^{\text {nd }}$ day with a single dose of the $M$. charantia (wild $50 \%$ ), wild $30 \%$, hybrid 50\%, hybrid $30 \%$ and gliben-

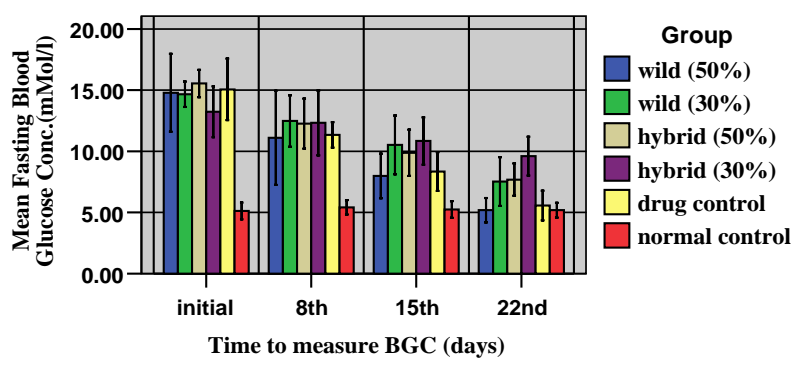

Figure 1. Chronic effect of M. charantia (Wild \& Hybrid) powder on fasting blood glucose Conc. Of alloxan induced type 2 diabetic model rats. All bars shows Mean \pm SD wild (50\%) are more significant than all other group.

Table 1. Chronic effect of M. charantia (Wild \& Hybrid) powder on fasting blood glucose Conc. Of alloxan induced type 2 diabetic model rats.

\begin{tabular}{|c|c|c|c|c|}
\hline Group & $\begin{array}{c}\text { Glu_Initial Day (mmol/l) } \\
(\text { Mean } \pm \text { SD) }\end{array}$ & $\begin{array}{c}\text { Glu_8 }{ }^{\text {th }} \text { day }(\mathrm{mmol} / \mathrm{l}) \\
(\text { Mean } \pm \text { SD) }\end{array}$ & $\begin{array}{c}\text { Glu_15 }{ }^{\text {th }} \text { day }(\mathrm{mmol} / \mathrm{l}) \\
(\text { Mean } \pm \mathrm{SD})\end{array}$ & $\begin{array}{c}\text { Glu_22 }{ }^{\text {nd }} \text { day }(\mathrm{mmol} / \mathrm{l}) \\
(\text { Mean } \pm \text { SD) }\end{array}$ \\
\hline Group-A (Wild 50\%) $(\mathrm{n}=5)$ & $14.78 \pm 1.59$ & $11.1 \pm 1.93$ & $7.98 \pm 0.91^{\mathrm{a}}$ & $5.18 \pm 0.50^{\mathrm{a}, \mathrm{b}, \mathrm{c}}$ \\
\hline Group-B (Wild 30\%) (n= 5) & $14.66 \pm 0.52$ & $12.48 \pm 1.05$ & $10.52 \pm 1.20$ & $7.52 \pm 1.00$ \\
\hline Group-C (Hybrid 50\%) $(n=5)$ & $15.54 \pm 0.56$ & $12.26 \pm 1.02$ & $9.88 \pm 0.94$ & $7.68 \pm 0.66$ \\
\hline Group-D (Hybrid 30\%) $(n=5)$ & $13.24 \pm 1.04$ & $12.32 \pm 1.33$ & $10.84 \pm 0.97$ & $9.6 \pm 0.79^{\mathrm{a}, \mathrm{b}}$ \\
\hline Group-E (Drug control) $(\mathrm{n}=5)$ & $15.06 \pm 1.25$ & $11.34 \pm 0.52$ & $8.34 \pm 0.79$ & $5.56 \pm 0.60^{\mathrm{a}, \mathrm{b}, \mathrm{c}}$ \\
\hline Group-F (Normal control) $(\mathrm{n}=5)$ & $5.12 \pm 0.34$ & $5.42 \pm 0.30^{\mathrm{a}, \mathrm{b}, \mathrm{c}}$ & $5.24 \pm 0.34^{\mathrm{a}, \mathrm{b}, \mathrm{c}}$ & $5.18 \pm 0.30^{\mathrm{a}, \mathrm{b}, \mathrm{c}}$ \\
\hline
\end{tabular}

Results are expressed as Mean \pm SD. SD = Standard Deviation. Among groups, comparison was done using one way ANOVA with post hoc Bonferroni P test. $\mathrm{BGC}=$ Blood glucose Conc.; Glu = Glucose; $\mathrm{n}=$ number of rats. Significant level ${ }^{\mathrm{a}} \mathrm{P}<0.05,{ }^{\mathrm{b}} \mathrm{P}<0.01$ and ${ }^{\mathrm{C}} \mathrm{P}<0.001$ vs. Hybrid $(50 \%)$. 
Table 2. Chronic effect of $M$. charantia (Wild \& Hybrid) powder on fasting serum lipidemic status (Total Cholesterol \& Triglyceride) of type 2 diabetic rats.

\begin{tabular}{ccccc}
\hline Group & $\begin{array}{c}\text { TC_Initial }(\mathrm{mg} / \mathrm{dl}) \\
(\text { Mean } \pm \text { SD) }\end{array}$ & $\begin{array}{c}\text { TC_22 }{ }^{\text {nd }}(\mathrm{mg} / \mathrm{dl}) \\
(\text { Mean } \pm \text { SD) }\end{array}$ & $\begin{array}{c}\text { TG_Initial }(\mathrm{mg} / \mathrm{dl}) \\
(\text { Mean } \pm \text { SD)D })\end{array}$ & $\begin{array}{c}\text { TG_22 }{ }^{\text {nd }}(\mathrm{mg} / \mathrm{dl}) \\
(\text { Mean } \pm \text { SD) }\end{array}$ \\
\hline Group-A (Wild 50\%) $(\mathrm{n}=5)$ & $69.40 \pm 6.23$ & $60.40 \pm 6.11$ & $83.8 \pm 7.09$ & $63.6 \pm 6.35$ \\
Group-B (Wild 30\%) $(\mathrm{n}=5)$ & $67.80 \pm 4.61$ & $64.20 \pm 5.07$ & $83 \pm 5.52$ & $77.4 \pm 6.27$ \\
Group-C (Hybrid 50\%) $(\mathrm{n}=5)$ & $65.40 \pm 4.72$ & $59.20 \pm 5.02$ & $72.8 \pm 3.49$ & $66.4 \pm 4.93$ \\
Group-D (Hybrid 30\%) $(\mathrm{n}=5)$ & $66.60 \pm 4.72$ & $65.00 \pm 5.87$ & $67.2 \pm 3.90$ & $66.8 \pm 1.48$ \\
Group-E (Drug control) $(\mathrm{n}=5)$ & $75.60 \pm 3.78$ & $64.20 \pm 4.21$ & $72 \pm 7.55$ & $59 \pm 7.75$ \\
Group-F (Normal control) $(\mathrm{n}=5)$ & $73.00 \pm 4.06$ & $68.40 \pm 4.67$ & $74.4 \pm 5.37$ & $72.4 \pm 4.88$ \\
\hline
\end{tabular}

Results are expressed as Mean \pm SD. SD = Standard Deviation. Among groups, comparison was done using one way ANOVA with post hoc Bonferroni P test. $\mathrm{TC}=$ Total Cholesterol; $\mathrm{TG}=$ Triglyceride; $\mathrm{n}=$ number of rats.

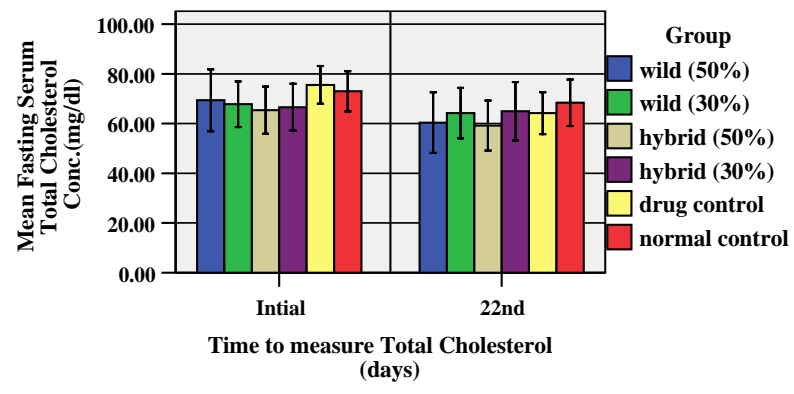

Figure 2. Chronic effect of $M$. charantia (Wild \& Hybrid) powder on fasting serum Total Cholesterol Conc. Of alloxan induced type 2 diabetic model rats. All bars shows Mean \pm SD and there are no significant changes in all groups.

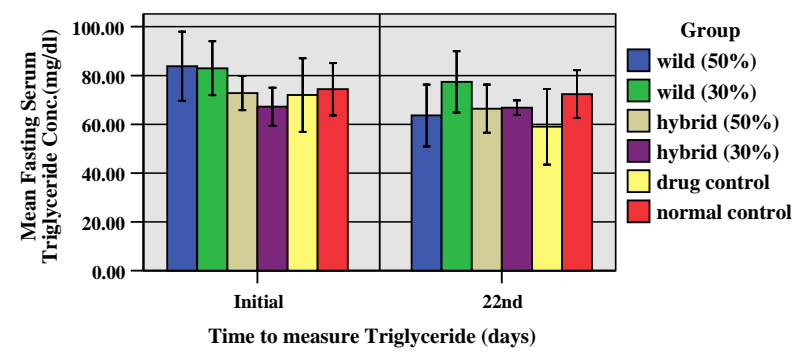

Figure 3. Chronic effect of $M$. charantia (Wild \& Hybrid) powder on fasting serum Triglyceride Conc. Of alloxan induced type 2 diabetic model rats. All bars shows Mean \pm SD and there are no significant change in all groups.

clamide, respectively. But, a significant reduction ( $\mathrm{P}<$ 0.05 ) in fasting serum triglycerides of 24.1, 6.75, 8.79 , .59 and $18.05 \%$ observed on the $22^{\text {nd }}$ day with a single dose of the $M$. charantia (wild $50 \%$ ), wild $30 \%$, hybrid 50\%, hybrid 30\% and glibenclamide, respectively.

However, the serum cholesterol lowering efficiency of $M$. charantia was found very lower than that of standard drug (glibenclamide). But wild 50\% was more significant than all other groups. On the contrary, M. charantia's wild $50 \%$ has the higher efficiency of lowering serum triglycerides with respect to wild $30 \%$, hybrid $50 \%$, hybrid 30\% and the standard drug.

\subsection{Chronic Effect of $M$. charantia (Wild \& Hybrid) Powder on Fasting Serum Lipidemic Status (HDL-C and LDL-C) of Alloxan Induced Type 2 Diabetic Rats}

The effect of $M$. charantia on atherogenic lipids (HDLcholesterol and LDL-cholesterol) is depicted in Table 3 \& Figure 4, 5 respectively. It seems that, there were no significant changes in case of HDL-cholesterol level among all the test groups after 21 days of chronic experiment. But there were significant changes in case of LDL-cholesterol level among all the test groups after 21 days of chronic experiment. The standard drug control group had pronounced HDL-cholesterol increasing effect (1.67\% increase from the initial value). But all the group (wild 50\%, wild $30 \%$, hybrid $50 \%$ and hybrid $30 \%$ ) was not increasing statistical significant ( $\mathrm{p}<0.05,0.01,0.001$ ) compared with normal and standard drug control. The standard drug control group had pronounced LDL-cholesterol decreasing effect $339.33 \%$ decreases from the initial value). And also wild 50\% and hybrid $50 \%$ significantly changed after 21 days feeding. The decreasing percentages were 27.54 and 34.55 . The significant level was compared on $\mathrm{p}<0.05,0.01,0.001$. The other groups such as wild $30 \%$, hybrid $30 \%$ and normal control were not significantly ( $<<0.05,0.01,0.001)$ changed after 21 days feeding.

\subsection{Chronic Effect of M. charantia (Wild \& Hybrid) Powder on Fasting Serum Insulin Concentration of Alloxan Induced Type 2 Diabetic Model Rats}

The chronic effect of $M$. charantia fruits (wild \& hybrid) powder on insulinemic status of type 2 diabetic model rats is shown in Table 4 and Figure 6. Serum insulin level significantly changed in wild $50 \%$ among all 
Table 3. Chronic effect of M. charantia (Wild \& Hybrid) powder on lipidemic status (HDL-C and LDL-C) of type 2 diabetic rats.

\begin{tabular}{ccccc}
\hline Group & $\begin{array}{c}\text { HDL-C_Initial }(\mathrm{mg} / \mathrm{dl}) \\
(\text { Mean } \pm \text { SD) }\end{array}$ & $\begin{array}{c}\text { HDL-C _22 }{ }^{\text {nd }}(\mathrm{mg} / \mathrm{dl}) \\
(\text { Mean } \pm \text { SD) }\end{array}$ & $\begin{array}{c}\text { LDL-C_Initial (mg/dl) } \\
(\text { Mean } \pm \text { SD) }\end{array}$ & $\begin{array}{c}\text { LDL-C_22 }{ }^{\text {nd }}(\mathrm{mg} / \mathrm{dl}) \\
(\mathrm{Mean} \pm \mathrm{SD})\end{array}$ \\
\hline Group-A (Wild 50\%) $(\mathrm{n}=5)$ & $34.92 \pm 2.23$ & $34.84 \pm 2.16$ & $17.72 \pm 5.02$ & $12.84 \pm 4.93$ \\
Group-B (Wild 30\%) $(\mathrm{n}=5)$ & $35.49 \pm 2.81$ & $35.48 \pm 2.88$ & $15.72 \pm 3.26$ & $13.24 \pm 3.50$ \\
Group-C (Hybrid 50\%) $(\mathrm{n}=5)$ & $36.83 \pm 1.62$ & $36.75 \pm 1.52$ & $14.01 \pm 3.49$ & $9.17 \pm 3.71$ \\
Group-D (Hybrid 30\%) $(\mathrm{n}=5)$ & $34.57 \pm 3.20$ & $34.55 \pm 3.32$ & $18.59 \pm 3.96$ & $17.09 \pm 4.07$ \\
Group-E (Drug control) $(\mathrm{n}=5)$ & $37.25 \pm 1.80$ & $37.87 \pm 2.06$ & $23.95 \pm 3.17$ & $14.53 \pm 3.96$ \\
Group-F (Normal control) $(\mathrm{n}=5)$ & $38.83 \pm 2.93$ & $38.65 \pm 3.21$ & $19.3 \pm 3.58$ & $15.27 \pm 4.15$ \\
\hline
\end{tabular}

Results are expressed as Mean \pm SD. SD = Standard Deviation. Among groups, comparison was done using one way ANOVA with post hoc Bonferroni P test. HDL-C = High Density Lipoprotein Cholesterol; LDL-C = Low Density Lipoprotein Cholesterol; $n=$ number of rats.

Table 4. Chronic effect of M. charantia (Wild \& Hybrid) powder on fasting Serum Insulin Conc. Of alloxan induced type 2 diabetic model rats.

\begin{tabular}{ccc}
\hline Group & Insulin_Initial (ng/ml) (Mean \pm SD) & Insulin_22 ${ }^{\text {nd }}(\mathrm{ng} / \mathrm{ml})(\mathrm{Mean} \pm \mathrm{SD})$ \\
\hline Group-A (Wild 50\%) $(\mathrm{n}=5)$ & $1.17 \pm 0.25$ & $2.00 \pm 0.35^{\mathrm{a}, \mathrm{b}, \mathrm{c}}$ \\
Group-B (Wild 30\%) $(\mathrm{n}=5)$ & $0.88 \pm 0.17$ & $1.01 \pm 0.17$ \\
Group-C (Hybrid 50\%) $(\mathrm{n}=5)$ & $0.55 \pm 0.10$ & $0.68 \pm 0.15$ \\
Group-D (Hybrid 30\%) $(\mathrm{n}=5)$ & $1.12 \pm 0.15$ & $1.16 \pm 0.08^{\mathrm{a}}$ \\
Group-E (Drug control) $(\mathrm{n}=5)$ & $1.28 \pm 0.16$ & $1.70 \pm 0.12^{\mathrm{a}, \mathrm{b}, \mathrm{c}}$ \\
Group-F (Normal control) $(\mathrm{n}=5)$ & $1.07 \pm 0.29$ & $1.25 \pm 0.30^{\mathrm{a}, \mathrm{b}}$ \\
\hline
\end{tabular}

Results are expressed as Mean \pm SD. SD = Standard Deviation. Among groups, comparison was done using one way ANOVA with post hoc Bonferroni P test; $\mathrm{n}$ $=$ number of rats. Significant level ${ }^{\mathrm{a}} \mathrm{P}<0.05,{ }^{\mathrm{b}} \mathrm{P}<0.01$ and ${ }^{\mathrm{c}} \mathrm{P}<0.001$ vs. Hybrid (50\%).

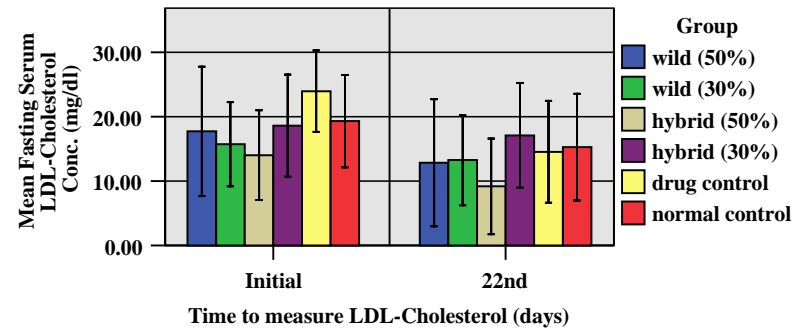

Figure 4. Chronic effect of $M$. charantia (Wild \& Hybrid) powder on fasting serum LDL-C Conc. Of alloxan induced type 2 diabetic model rats. All bars shows Mean \pm SD and there are no significant changes in all groups.

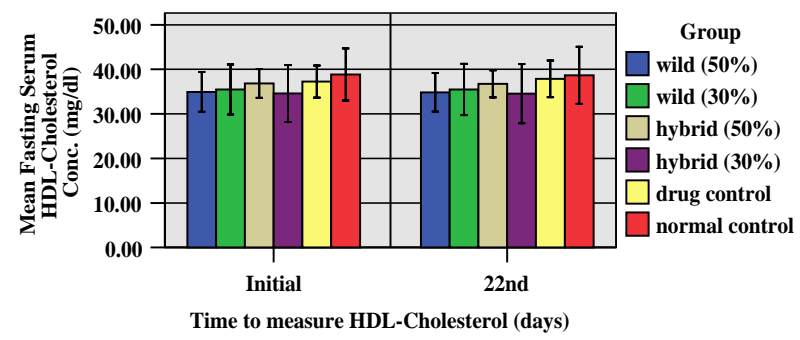

Figure 5. Chronic effect of M. charantia (Wild \& Hybrid) powder on fasting serum HDL-C Conc. Of alloxan induced type 2 diabetic model rats. All bars shows Mean \pm SD and there are no significant changes in all groups.

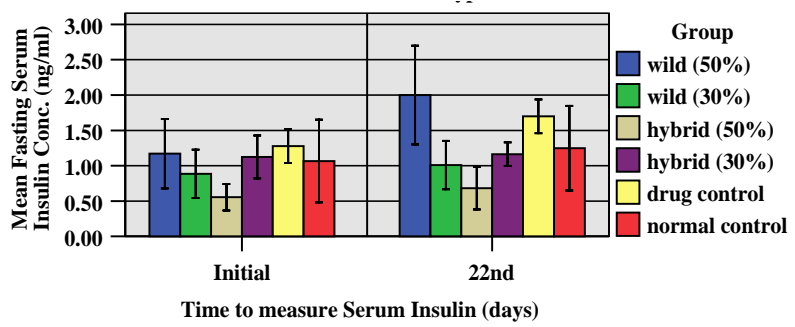

Figure 6. Chronic effect of M. charantia (Wild \& Hybrid) powder on fasting serum Insulin Conc. Of alloxan induced type 2 diabetic model rats. All bar shows Mean \pm SD and wild (50\%) are more significant than all other groups.

other test groups after 21 days of chronic feeding. The significant ( $p<0.05,0.01,0.001$ ) was applied. The Table 4 and Figure 6 shows wild 50\% was significantly higher about $71 \%$ compared with other groups. The standard drug control group showed higher significant about 33\%. Other group wild 30\%, hybrid 50\%, hybrid $30 \%$ and normal control changed very little bit as 14.77 , 23.64, 3.57 and $16.82 \%$ respectively.

\section{DISCUSSIONS}

Diabetes is a metabolic disorder which can be consi- 
dered as a major cause of high economic loss which can in turn impede the development of nations [21]. The development of research into new hypoglycaemic and hypolipidemic agents is of great interest. Many families of plants with the most potent hypoglycaemic effects include: Cucurbitaceae. It's most valuable species $M$. charantia which have hypoglycemic and hypolipidemic activity.

My present study was undertaken to compare the hypoglycemic and hypolipidemic activity of $M$. charantia's two variety wild and hybrid. In the present investigation, it was found that in type 2 diabetic model rats alloxan produce significant increase in fasting blood glucose concentration on the $3^{\text {rd }}$ day to inject alloxan the concentration was ranging between $13.24 \pm 1.04 \mathrm{mmol} / \mathrm{l}$ and $15.54 \pm 0.56 \mathrm{mmol} / \mathrm{l}$. Alloxan is a toxic glucose analogue, which selectively destroys insulin-producing cells ( $\beta$-cell) in the pancreas [22].

Daily feeding of the powder of $M$. charantia (wild and hybrid) for 21 days resulted in decrease in the blood glucose levels of alloxan-induced diabetic rats. The wild $50 \%$ was significantly $(\mathrm{p}<0.05)$ decreased glucose level $65 \%(14.78 \mathrm{mmol} / \mathrm{l}$ to $5.18 \mathrm{mmol} / \mathrm{l})$ after 21 days. While wild $30 \%$, hybrid $50 \%$, hybrid $30 \%$ and glibenclamide were decreased $48 \%, 52 \%, 27 \%$ and $63 \%$ respectively. The effect of wild $50 \%$ is more significant than Standard drug (glibenclamide) for diabetic subject. The possible mecha- nism by which powder brings about its hypoglycemic activity may be the potentiating the insulin effect of plasma by increasing either the pancreatic secretion of insulin from the existing $\beta$-cells or by its release from the bound insulin [23]. M. charantia contain flavonoids and tannins, this known to possess antidiabetic activity.

Hyperlipidprofile have been occurred by the induction of alloxan to the model rats. The hypercholesterol was not significantly $(\mathrm{p}<0.05)$ decreased but hypertriglyceride concentration was significantly $(\mathrm{p}<0.05)$ decreased $24 \%$ compared with other group after 21 days orally feeding of $M$. charantia fruit powder. The HDL-Cholesterol was not significantly $(\mathrm{p}<0.05)$ decreased or increased after 21 days. But LDL-Cholesterol concentrations were significantly $(\mathrm{p}<0.05)$ decreased about $28 \%$ by feeding wild $50 \%$. Hybrid $50 \%$ was more significant than wild $50 \%$.

In the absence of insulin, protein production is not favored $[24,25]$. Treatment with powder has shown a significant decreased in the serum cholesterol, serum triglycerides indicating an increase in insulin level.

The present study have shown significant $(\mathrm{p}<0.05)$ increase about $71 \%$ of serum insulin level after 21 days feeding, where other sample low effective. For increaseing insulin which results in activation of glycogen syntheses system. There were significant increase liver glycogen levels. Thus $M$. charantia represent the antidia- betic action. It may be due to improvement of glycolgenesis.

M. charantia (wild 50\%) may prevent more than other sample i.e. the ongoing $\beta$-cells damage, recovery of partially damaged $\beta$-cells, and regeneration of new cells and stimulate insulin secretion and significantly lower the blood glucose level (hypoglycemic activity) and significantly decrease lipid level (hypolipidemic activity).

\section{CONCLUSION}

The obtained results suggest the Momordica charantia (wild 50\%) significantly more improves glycemic and lipidemic serum insulin level status in type 2 diabetic model rats than other study groups. The plant needs further detailed investigation to identify their active princeples and mode of action.

\section{ACKNOWLEDGEMENTS}

We gratefully acknowledge the financial and logistic supports provided by the Animal Research Section, Institute of Food Science and Technology (IFST), BCSIR, Dhaka, Bangladesh.

\section{REFERENCES}

[1] Ogbonnia, S.O., Odimegwu, J.I. and Enwuru, V.N. (2008) Evaluation of hypoglycemic and hypolipidemic effects of ethanolic extracts of Treculia africana Decne and Bryophyllum pinnatum Lam. and their mixture on streptozotocin (STZ)-induced diabetic rats. African Journal of Biotechnology, 7, 2535-2539.

[2] Edem, D.O. (2009) Hypoglycemic effects of ethanolic extracts of alligator pear seed (persea americana mill) in rats. European Journal of Scientific Research, 33, 669678.

[3] Kristova, V., Liskoya, S., Sotnikova, S., Vojtko, R. and Kurtansky, A. (2008) Sulodexide improves endothelial dysfunction in streptozotocin-induced diabetes in rats. Physiological Research, 5, 491-494.

[4] World Health Organization (WHO) (1999) Definition, diagnosis and classification of diabetes mellitus and its complications, Part 1: Diagnosis and classification of diabetes mellitus. Report of a WHO consultation. Department of Non communicable Disease Surveillance, WHO, Geneva.

[5] American Diabetes Association (ADA) (2005) Diagnosis and classification of diabetes mellitus. Diabetes Care, 28, 37-42. doi:10.2337/diacare.28.suppl_1.S37

[6] Bastaki, S. (2005) Review diabetes mellitus and its treatment. International Journal of Diabetes and Metabolism, 13, 111-134.

[7] Trivedi, N.A., Majumder, B., Bhatt, J.D. and Hemavathi, K.G. (2004) Effect of Shilajit on blood glucose and lipid profile in alloxan-induced diabetic rats. Indian Journal of Pharmacology, 36, 373-376.

[8] Saravanan, R., Rajendra Prasad, N. and Pugalandi, K.V. 
(2003) Effect of Piper betle leaf extract on alcoholic toxicity in the rat brain. Journal of Medicinal Food, 6, 261265. doi:10.1089/10966200360716689

[9] Edijala, J.K., Asagba, S.O., Eriyamremu, G.E. and Atomatofa, U. (2005) Comparative effects of garden egg fruit, oat and apple on serum lipid profile in rats fed on a high cholesterol diet. Pakistan Journal of Nutrition, 4, 245249. doi:10.3923/pjn.2005.245.249

[10] Gerstein, H., Yusuf, S., Bosch, J., Pogue, J., Sheridan, P., Dinccag, N., Hanefeld, M., Hoogwerf, B., Laakso, M., Mohan, V., Shaw, J., Zinman, B. and Holman, R., (2006) Effect of rosiglitazone on the frequency of diabetes in patients with impaired glucose tolerance or impaired fasting glucose: A randomised controlled trial. Lancet, 368, 1096-1105. doi:10.1016/S0140-6736(06)69420-8

[11] Kjeldsen, S.E., Julius, S., Mancia, G., McInnes, G.T., Hua, T., Weber, M.A., Coca, A., Ekman, S., Girerd, X., Jamerson, K., Larochelle, P., Macdonald, T.M., Schmieder, R.E., Schork, M.A., Stolt, P., Viskoper, R., Widimsky, J. and Zanchetti, A. (2006) Effects of valsartan compared to amlodipine on preventing type 2 diabetes in high-risk hypertensive patients: The VALUE trial. Journal of Hypertension, 24, 1405-1412. doi:10.1097/01.hjh.0000234122.55895.5b

[12] Dahanukar, S. A., Kulkarni, R.A. and Rege, N.N. (2000) Pharmacology of medicinal plants and natural products. Indian Journal of Pharmacology, 32, 81-118.

[13] Aslam, M. (1979) Interaction between curry ingredient and drug. Lancet, 17, 607. doi:10.1016/S0140-6736(79)91028-6

[14] Cupts, S.S. and Seth, C.B. (1982) Effect of momordica charentia Linn. (karela) on glucose tolerance in albino rats. Journal of Indian Medical Association, 39, 581-584.

[15] Wang, W., Miura, T., Shi, H., Ma, D.M., Zhao, Q.D., Zhang, W.P., Ishihara, E., Kanehara, M., Zhang, B.L., Gao, X.M., Zhang, D.Q. and Ishida, T. (2008) Effect of Tangzhiqing on glucose and lipd metabolism in genetically type 2 diabetes KK-Ay mice. Journal of Health Science, 54, 203-206. doi:10.1248/jhs.54.203

[16] Konkon, N.G., Adjoungoua, A.L., Manda, P., Simaga, D., N'Guessan, K.E. and Kone, B.D. (2010) Toxicological and phytochemical screening study of Mitragyna Inermis (willd.) O ktze (Rubiaceae), anti diabetic plant. Journal of
Medicinal Plants Research, 2, 279-284.

[17] Grover, J.K. and Yadav, S.P. (2004) Pharmacological actions and potential uses of Momordica charantia: A review. Journal of Ethnopharmacology, 93, 123-132. doi:10.1016/j.jep.2004.03.035

[18] Akhtar, M.S., Athar, M.A. and Yaqub, M. (1981) Effect of Momordica charantia on blood glucose levels of normal and alloxan diabetic rabbits. Planta Medica, 42, 205-212. doi:10.1055/s-2007-971629

[19] Lenzen, S. (2008) The mechanisms of alloxan- and streptozotocin-induced diabetes. Diabetologia, 51, 216226. doi:10.1007/s00125-007-0886-7

[20] Khan, Cr. and Shechter, Y. (1991) Oral hypoglycemic agents and the pharmacology of the endocrine pancreas. In: Theodore, W.R., Alan, S.N., Taylor, P. and Gilman, Ag, Eds., Goodman and Gilman's the Pharmacological Basis of Therapeutics, 8th Edition, McGraw-Hill, New York.

[21] Mahabir, D. and Gulliford, M.C., (1997) Use of medicinal plants for diabetes in Trinidad and Tobago. Rev Panam Salud Publica, 1, 174-179. doi:10.1590/S1020-49891997000300002

[22] Grover, J.K., Vats, V. and Rathi, S.S. (2000) Antihyperglycemic effect of Eugenia jambolana and Tinospora cordifolia in experimental diabetes and their effects on key metabolic enzymes involved in carbohydrate metabolism. Journal of Ethnopharmacology, 73, 461-470. doi:10.1016/S0378-8741(00)00319-6

[23] Shirwaikar Annie, Rajendran, K. and Rakesh, B. (2006) Effect of aqueous bark extracts of Garuga pinnata in streptozotocin-nicotinamide induced type-II diabetes mellitus. Journal of Ethnopharmacology, 107, 285-290. doi:10.1016/j.jep.2006.03.012

[24] Herfindal Eric, T. and Gourley Dick, R. (2001) Drug and disease management. In: Williams, L. and Wilkins, Text Book of Therapeutics, 7th Edition, McGraw-Hill Press, New York, 382-383.

[25] Dhanraj, S., Archana, J., Inder, S. and Goyal, P.K. (2007) Modulation of radiation-induced biochemical alteration in mice by rosemary (Rosmarinus officinalis) extract. Phytomedicine, 14, 701-705. doi:10.1016/j.phymed.2006.12.011 